\title{
The use of hebel in Ecclesiastes: A political and economic reading
}

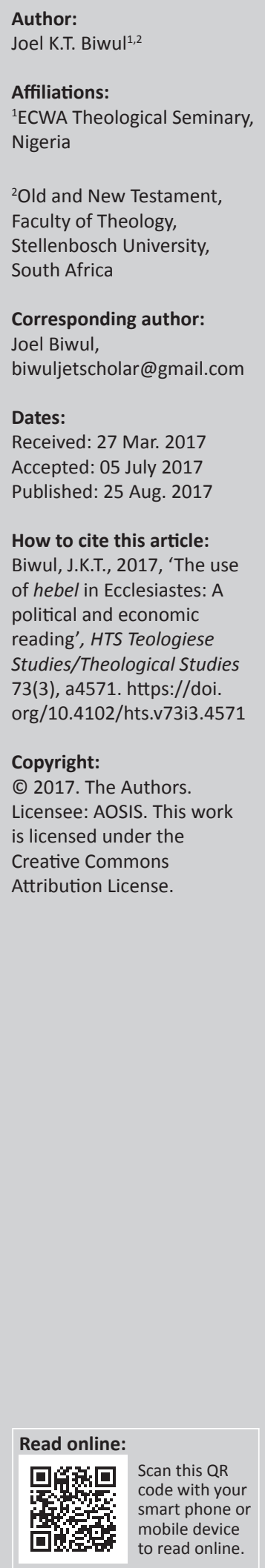

A hermeneutical cloud still dominates ongoing discourse on the meaning and application of הֶבֶל (hebel), a crucial weaving thread in the book of Ecclesiastes. The Hebrew Qoheleth, presumably the disguised author, proposes the theological ideology of hebel as the totality of human existence in this book. What does Qoheleth intend to achieve by asserting and dismissing everything in human experience as hebel (vanity, meaningless, worthless, not beneficial, absurd and enigma)? This article proposes a political and economic reading of Ecclesiastes, holding that the author, from personal observation, saw and addressed life from the point of view of ivory tower aristocrats who sought to control their environment by every means to their benefit. It suggests that a political and economic reading of Ecclesiastes locates another perspective on Qoheleth's purposes for the use of hebel. As such, it argues that the Qoheleth uses hebel as a literary rhetorical device as an evaluative grid to critique and indict the negative behaviour of the politically powerful and the wealthy, to caution against the reckless abuse of political and economic power to their benefit by those who live in privilege in society, and lastly to give counsel for an appropriate application of such privileged power for the good of society vis-à-vis the transitory, transient and unpredictable nature of human existence.

\section{Introduction}

The propositions and assertions of the Qoheleth in Ecclesiastes, dismissing everything in human הֶֶָ (hebel), will most likely continue to generate hermeneutical discourse for generations to come. Meek (2016) is right in positing that the meaning of in a crux interpretum ${ }^{1}$ for the book of Ecclesiastes, in particular that little consensus has been reached regarding its meaning. Ecclesiastes is considered as the most difficult book of the Bible to understand in view of its structure and theology (Habtu 2006:787) and as 'one of the most puzzling books of the Bible' (Wright 1991:1137) for the presence of 'riddles and ambiguities' (Ingram 2013:485). Such difficulty not only allows for different interpretive perspectives but also forces scholars to date it either to the Solomonic era or to the Persian, Ptolemaic and/or Hellenistic era in the fifth, fourth or third centuries. Consequently, 'one's translation and understanding of will largely determine one's understanding of the book as a whole. This cannot be emphasized enough!' (Reed 2012:155).

The repeated occurrence of the use of hebel suggests that Ecclesiastes is a book that calls for careful ideological, philosophical, anthropological, ethical and, in particular, theological reflection to comprehend over against the enigmatic realities of human existence. ${ }^{2}$ The emphatic sonorous voice of the Qoheleth ${ }^{3}$ that is heard in Ecclesiastes appears both intriguing and fascinating for the irrational and irreconcilable realities described therein as hebel. Scott translates hebel as 'vapour' or 'breath', connoting 'what is visible and recognizable, but unsubstantial, momentary, and profitless' (1965:202). Such expression presents the theme of futility and frustration, demonstrating the vanity and pointlessness of all things (Harrison 1969:1078). Waltke understands hebel as 'absurdity' and 'nonsense' and claims Qoheleth uses hebel 'for that which is "unsubstantial," "fleeting" and

1.The phrase crux interpretum literally means 'cross of the interpreters' in Latin. When used for hebel in Ecclesiastes, it therefore means suggestively that its meaning is difficult or impossible to interpret and resolve.

2.Provan (2001) explains that Ecclesiastes is considered a difficult book on the ground that its form of Hebrew is different; its grammar and syntax are challenging; its frequently used words are not only unclear but also disputed in terms of interpretation, particularly the Qoheleth's use of wordplay; and its arguments are also complex and sometimes puzzling. Yet, he suspects that the seeming difficulties encountered in Ecclesiastes may well be that: the problem lies not with the book but with ourselves. The 'difficulty' may be that the book speaks truly about reality while we are devoted to illusions. The 'difficulty' may be that we are not too keen to embrace the truth, but prefer to embrace half-truth's and lies (2001:23, 25). Provan's statements are worth the careful attention of scholarship in the ongoing debate.

3.Seow explains that the title Ecclesiastes is the Latin transliteration of the Greek rendering of the pen name of the author in the Septuagint (2001:944). Also, the Hebrew 2 (Qoheleth) translated as the Teacher (NET, NIV, NLT, NRS) and the Preacher (ASV, ESV, KJV, NAS, NKJ, GNV, RSV) also means speaker, an assembler, a sage, a gatherer and a philosopher. Murphy suggests that Qoheleth is to be understood as a designate of a professional title or an office rather than a proper name (1992:xx). Others, however, suspect that it

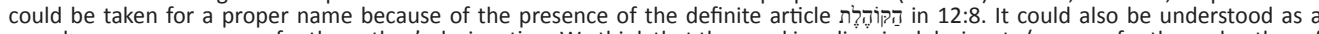
pseudonym or an acronym for the author's designation. We think that the word is a disguised designate/persona for the real author of Ecclesiastes. 
"lacking in permanence" for specific situations for which mortals can find no answer and in that sense are "enigmatic or illusory"' (2007:956).

Qoheleth, the purported author, uses hebel as a key search word to assert several things as hebel (Eccl 1:2, 14; 12:8). A cursory preview indicates that the things the Qoheleth asserts are hebel, among other things, include pleasure $(2: 1-3,10)$, hard work and achievements (2:4-11), wisdom (2:12-16), labour (2:17-23;4:4), self-deprivation (4:7-8), human craving for wealth $(5: 10-13 ; 6: 2)$, human pitiful exit $(6: 2-3)$ and the irreconcilable manner in which the righteous and the wicked are rewarded $(7: 15 ; 8: 14-15)$.

The pervasive presence of the language of politics and economy in Ecclesiastes demands space in academic discourse in relation to the use of Does a hermeneutical possibility exist to also consider Qoheleth's use of hebel as his employing a royal political and economic literary rhetorical device to evaluate, critique and advise the politically and economically powerful of his society to rather use such privileges for society's benefit vis-à-vis the transitory nature of life?

This study calls attention to Qoheleth's use of hebel with a political and economic focus. It reads the text against the context of the oppressive manipulative political control by the powerful of the powerless, voiceless and the downtrodden, and against the economic context of the extremely rich versus the extremely poor in Qoheleth's society, and no less in today's society. Consequently, it proposes that a political and economic reading of this religious text adds to its hermeneutical understanding which then becomes more meaningful to its modern readers in an oppressive and depriving social, political and economic environment.

\section{The nature of the book of Ecclesiastes and the identity of the Qoheleth}

\section{The nature of Ecclesiastes}

According to Robert Chisholm, 'To appreciate fully the meaning of a text, one must understand the historical context from which it derives and the cultural realities that it reflects and assumes' (Chisholm 1998:149). The quest to understand Qoheleth's use of hebel in Ecclesiastes requires situating the historical context in view of the cultural realities of political and economic oppression of the day.

The book's unique nature forces scholars such as R.B.Y. Scott to concede Ecclesiastes as the strangest book in the Bible, whose presence in the canons of Judaism and Christianity is most inexplicable because it stands alone in almost every respect (1982:191-193). Such a view leads Roland Murphy to explain that the book has suffered excessive summarisation for lack of pinning down one unitary picture of the work. As he puts it, 'Qoheleth's thought is torturous, and the danger of selectivity on the part of the interpreter is ever present' (1992:lviii). Accordingly, William Provan explains the difficulty when he asserts that Ecclesiastes 'is a book that grapples with reality, and reality is complex. Should the words of a wise man about reality not be difficult to simplify?' (2001:23, 33). In essence, the book allows 'plenty of scope for differences of interpretation' (Ingram 2013:497).

Such inherent complexity further compels some scholars to deprive the Qoheleth a hearing for his deterring presentation. In what Stephen Curkpatrick calls a performative response to his work, he opines that the Qoheleth is the most misunderstood and neglected of the Judeo-Christian traditions because of the ambiguity and paradox that pervade his work. In his letter of response, Curkpatrick describes him as follows:

\begin{abstract}
... you are the most ironic writer of the biblical tradition. You do not have time for theology divorced from life or piety, theology that does not ring true to people's life experiences, and you make the point with pithy irony. Most people, understandably, can only cope with small doses of your kind of realism. (2001:286)
\end{abstract}

In addition to this ironic perception is George Hendry's description of the book: 'Ecclesiastes is in many respects an enigmatic book. Disjointed in construction, obscure in vocabulary, and often cryptic in style, it baffles the understanding of the reader' (1981:570).

Unarguably, as the foregoing perceptions reveal, careful readers of Ecclesiastes would discover that tensions and seemingly apparent contradictions encountered in it never go away. Elsa Tamez points (2001) out this issue quite clearly:

The book of Ecclesiastes is not an easy read; it is full of contradiction and exhibits a structure that can be found only after juggling all its parts. For this reason, the work opens itself to diverse interpretations, ranging from extreme pessimism to optimism. Hence, the fundamental problem in a book like Ecclesiastes is that of interpretation. (p. 250)

For instance, the author says or expresses the benefit of something and then counters it again as hebel. Such tensions reveal a juxtaposition of the pair of two poles in human life the pole of joy and pain, peace and upheaval, enjoyment and regrets, successes and failures, victory and defeat, wisdom and foolishness, freedom and oppressions, royalty and peasantry, possession and poverty, and happiness and despair. Tremper Longman describes the book as deeply enigmatic but tremendously compelling, a complex and profound book whose interpretation has intrigued generations of its readers $(2008: 140,148)$. To other critical scholars also, why and how the book finds its way into the Jewish canon as well as its proper use as Holy Scripture makes it a historical and theological enigma (Asa 2009:55). ${ }^{4}$

4.The complexities in Ecclesiastes are not without criticism. Zuck (1991) echoes the concern of critics who consider the book of Ecclesiastes as a misfit in the biblical cancen, especially in the wisdom corpus, because it seems to underscore the futility canon, especially in the wisdom corpus, because it seems to underscore the futility and uselessness of work, the triumph of evil, the limitation of wisdom. It apparently contradicts other portions of Scripture and presents a pessimistic outlook on life, in a mood of existential despair (p. 243).

Peter Enns presents two reasons why the book of Ecclesiastes poses a hermeneutical challenge: firstly, the book's message 'seems to be at odds with theological trajectories evident elsewhere in the Hebrew Scriptures', and, secondly, it is 'dotted with noticeable internal inconsistencies' (2008:121). 
From the above-mentioned discussion, Ecclesiastes has and probably will continue to pose both hermeneutical and theological questions to the readers. Miller suggests that this tension arises as though the Qoheleth forgot to include the key to unlock his thoughts (2000:215). Accordingly, Waltke asserts, 'The book of Ecclesiastes is the black sheep of the canon of biblical books. It is the delight of skeptics and the despair of saints' (2007:946).

Agreeably, the point of hermeneutical methodology will continue to be a leading issue in the book of Ecclesiastes such that a consensus opinion appears far remote. The tensions and complexities encountered by scholars regarding Ecclesiastes validate the presence of hebel in it. Qoheleth then is to be understood as using hebel as a catchword and as a literary rhetorical device to get his message across.

\section{The identity of the Qoheleth}

A conceptual understanding of the identity of the Qoheleth and the cultural and historical context and timeframe of Ecclesiastes helps to set the frame and tone for our political and economic reading of this literary product. While the focus of this article is on the author's purpose for using hebel, it seems expedient to give brief space to its authorship because this is critical for the entire article. According to Dominic Rudman, 'The Book of Ecclesiastes is a notoriously difficult text to date with any certainty' (1999:48). The book's author/speaker, frame narrator, or the implied narrator, and hence the author, is identified only descriptively as Qoheleth, ${ }^{5}$ but not named. He is understood as an unidentified Hebrew 'sage and gatherer of wealth and wisdom' (Seow 2001:944). Waltke (2007) thinks Qoheleth has been mistaken as the real author. While admitting that the identity of the narrator is unknown, he suspects the implied narrator to be an inspired sage and Qoheleth as his son. Hence, he assumes that probably:

Qoheleth is the narrator's fictitious literary creation of himself ... [who] in teaching his son inspired wisdom, the narrator represents himself as an equal to Solomon without claiming to be Solomon. (p. 948$)^{6}$

Traditionally, 'the most natural reading' (Longman 1998:4) of Ecclesiastes was assigned to Solomonic authorship on the basis of its superscription 'son of David, king in Jerusalem' (Eccl 1:1) and other internal referents such as 'I, the Teacher, was king over Israel in Jerusalem' (Eccl 1:12); 'I have grown and increased in wisdom more than anyone who has ruled over Jerusalem before me' (Eccl 1:16); and 'I also owned more herds and flocks than anyone in Jerusalem before me' (Eccl 2:7, 9) (see Provan 2001:26). Longman reports that 'the predominant opinion of the past is that in Ecclesiastes an old and repentant Solomon looks back over

5.The word Qoheleth is understood differently as a pen name, a pseudonym, a title designation, a personification and as a descriptive term, rather than as a real name ascribed to the book's real author.

6. Harrison (1969) reasons that if Ecclesiastes is assumed to be a legitimate product of: a Semitic sage rather than the direct composition of the renowned king of Israel, it is possible to place the work firmly within the didactic categories of ancient Hebrew wisdom ... a manual of instruction for successful living based upon certain philosophical presuppositions (p. 1073). his life, particularly the period after his apostasy from the Lord' and writes from a regrettable wasteful life 'to teach others of the dangers of wandering from the true God' (1998:2; see 1 Kgs 11:1-13).

But modern scholarship has challenged this thinking. Murphy situates it in the postexilic period and denies any identification with Solomon or any Hebrew (1992:xxi). Longman equally denies that Ecclesiastes was 'written by King Solomon in the tenth century B.C.' (1998:3). Also, Provan argues that the real historical location of the speaker is at some distance from the era of Solomon, and 'many of the later passages in Ecclesiastes appear to be written from a non-Solomonic point of view' (2001:26).

The absence of vivid authorial identity in Ecclesiastes gives room for much speculations and a seemingly unending scholarly debate. While the traditional view lends support to Solomonic authorship, a critical view subscribes to an author in the Persian, Ptolemaic and/or Hellenistic period. Although Solomonic authorship is becoming less attractive, either point of view is not easily dismissed. For instance, Longman III and Dillard correctly assert that internal considerations are of paramount importance in determining the date and authorship of a book' (2007:281). Yet, this principle is not easily applied to Ecclesiastes as the text suggests dual authorship - the prologue (1:1-11), main text $(1: 12-12: 8)$ and the epilogue (12:8-14). Readers encounter two voices within Ecclesiastes - 'Qoheleth and a second wise man, the latter being the narrative voice in control of the book'. One speaks in the third person in both prologue and epilogue, while the other speaks in first person in the main text (Longman \& Dillard 2007:282).

That Qoheleth poses as King Solomon (Branick 2006:79) gains support from internal evidence $(1: 1,2,12,16 ; 2: 4-9 ; 7: 26-29$; 12:9; see also 1 Kgs 2:9; 3:12; 4:29-34; 5:12; 10:1-8). Crenshaw supports this thinking, 'The book of Ecclesiastes consists of personal observation and reflection. The subject doing the reflecting is not just anyone; instead, this astute observer assumes the persona of King Solomon, the wisest of men' (1998:128). Scholars from this persuasion ground their argument in Solomonic wisdom tradition. ${ }^{7}$ Some readers, however, discount such authorial assumption on the ground

7.One of the factors that have generated continuous discourse on the book of Ecclesistes is a lack of scholarly consensus about its authorship. While few hold to Ecclesiastes is a lack the Solomonic era, majority hold to a postexilic timeframe, and a few more propose its anonymity. Although the superscript identifies the writer or speaker/frame narrator as king, some argue that the book's content betrays royalty in favour of a philosophical ideologist, teacher or propagandist. Seow (2001:944) says the perspective in most of the book is that of an outsider to the royal court (see also Eccl 3:16; 4:13-16; 8:1-6; 10:16-20). Paradoxically, royal language pervades the text. As a repository of wisdom, perhaps, Solomon's likely influence on this work rather than an exclusively Persian, Ptolemaic and/or Hellenistic dating is not to be dismissed in a hurry. Solomon's reputation was outstanding (Murphy 1992:17). The indelible presence of a Solomonic literary imprint on Hebrew poetry and wisdom literature adds to this outstanding reputation (Zuck 1991:207-208). Consequently, the argument for the use of hebel within political and economic domains is to the argument for the use of hebel within political and economic domains is to extend to Solomon's era as well. To ignore this consideration is to ignore the reality of such oppression in such an oppressive society. If the context of Ecclesiastes is detached from the Solomonic era, and if Solomon is not himself the Qoheleth, then it is logical to conclude that the Qoheleth assumed a royal persona to describe the ethos and the empirical reality of the Ptolemaic/Hellenistic Palestine of his day. Thi way, Qoheleth uses his empirical autobiographical data as an interpretive lens to convey his message and impact the entire message of the book of Ecclesiastes (Levicheva 2014:45) 
of the style of some aspects of the book (Eccl 4:1-2; 5:8-9; $8: 2-4 ; 10: 20){ }^{8}$

Additionally, Solomon represented himself in different respects to Israel in terms of his role as a monarch: in his contribution to wisdom literature and poetic literature in the area of musicology, in his achievement in warfare and developmental projects, in his act of covenant infidelity and religious distortion and so on. ${ }^{9}$ David R. Jackson (2008) states:
... while Solomon stands out most brightly as the one who serves to bring Israel to the climax of their national history as the chosen people of God, he is also the most prominent example of personal and public unfaithfulness ... [this] must be taken into account in any attempt to interpret both the man and the texts associated with his name. (p. 736)

However, scholars who hold to a postexilic Persian, Ptolemaic and/or Hellenistic composition of Ecclesiastes (Ingram 2013:489) will readily discount this proposal. For instance, Boadt (1984:484) asserts, 'That the author was Solomon is implied by the first verse when it says Qoheleth was the son of David in Jerusalem, but cannot be taken as fact'. To push the argument further, Scott (1965) posits that the language in which the book is written is:

a kind of Hebrew unlike any other in the Old Testament. It has features which resemble the Hebrew of the Mishna (A.D. 200), and of the somewhat earlier copper scroll from Qumran. (p. 192)

As the name of Solomon is absent in the book other than the author's identity description (1:12-13, 16; 2:1-9), Scott (1965) contends on this basis that:

the writer pictures himself, for the purpose of argument, in the role of the Solomon of legendary wealth and wisdom. ... The editor's biographical notes in xii 9-10 do not suggest even remotely that Qoheleth was in fact a king, let alone Solomon ... in Qoheleth, the role of Solomon manifestly is assumed for literary effect. (pp. 195, 197)

8.Until the birth of form criticism, Solomonic authorship was not questioned by majority scholarship. It was Grotius' form proposal to the effect that Ecclesiastes is majority scholarship. It was Grotius' form proposal to the effect that Ecclesiastes is
a collection of opinions sandwiched with that of the author that positioned him as ' the follection of opinions sandwiched with that of the author that positioned him as 1999:5). Bartholomew (1999) concludes from his survey of various scholarly interpretive stances on Ecclesiastes when he said: 'Very few scholars defend Solomonic authorship nowadays: most regard Ecclesiastes as written by an unknown Jew around the late 3rd century BC. Most scholars regard the book as a basic unity with the exception of the epilogue' (p. 6). Yet, according to Rudman, 'For the time being, the debate on the date of the Book of Ecclesiastes cannot be considered closed' (1999:52). As authorial consensus is lacking, although majority support a later date, few would still consider the possibility of dual authorship. They assume that King Solomon composed a larger part of the original material of Ecclesiastes, that King Solomon composed a larger part of the original material of Ecclesiastes, whose moral ideology and wisdom tradition was reworked, reinterpreted an replicated by a later collector or editor, to meet the need of Jewish wisdom in Solomonic tradition in Yehud community. Such a position on a reinterpretation by later generations of the postexilic Yehud community to reflect its reality is sympathetic not to negate Solomonic literary presence in Ecclesiastes. Yet, strong evidence in support is lacking.

9.Victor Hamilton (2004) describes King Solomon as an 'amazingly paradoxical character'. The screen play of such paradox reveals him as: somebody capable of both loving God (3:3) and loving many foreign women who do not love his God (11:1), of exercising incredible wisdom (3:16-28) and incredible stupidity, of accumulating a great number of proverbs and wise sayings (3000 and 1005 [4:32]) and an impressive number of wives and concubines (700 and 300) (p. 379). As globally acclaimed figure of his day, much so for his endowed wisdom, one would suspect that Solomon's marriage to many foreign wives was politically motivated for suspect that solom the gains of transnational trade; and also, it was most likely to demonstrate his status among his peers as monarch. But his flagrant defiance of Deut 17:17 regarding royal accumulation of wives became an 'occasion for the sin of idolatry' (Hamilton 2004:404) for both the king and his subjects. Consequently, the Qoheleth's use of hebel could retrogressively be expanded to also serve as an $\mathrm{X}$-rayed assessment of his own experience in his old age. Does any of the things people crave for ever satisfy?
It is more convincing, rational and persuasive, in view of extant literature, to situate the book to a postexilic period in a Ptolemaic and/or Hellenistic context as a more favourable date. This development gains more scholarly acceptance as scholars compare the language, vocabulary, style, syntax and thought of Ecclesiastes to late Hebrew and Aramaic (Longman 1998:10). According to Brown, the linguistic style and thought in Ecclesiastes suggest a relatively late date for its composition. Specifically, 'Persian loan words, Aramaisms, and late developments in Hebrew form and syntax all indicate a fourth or third century B.C. dating for the book' (2000:8). Provan admits difficulties in Ecclesiastes, including its grammar and syntax: 'When considered in the larger context of the Old Testament, Ecclesiastes stands out as an unusual book whose connection with the main stream of biblical tradition seems tenuous' (2001:23). According to him, the anonymous author 'was probably a postexilic writer who stood within the wisdom tradition of ancient Israel' (2001:26). Murphy also favours a Hellenistic era around $250 \mathrm{BC}$ when he observed, 'one may grant that there is a Hellenistic coloring to the types of courtly characters mentioned in the book' (1992:xxii, xxiv).

In view of the overwhelming evidence for later dating, Bartholomew reports that Solomonic authorship is falling out of scholarly popularity: 'most regard Ecclesiastes as written by an unknown Jew around the late third century BC' (1999:7). ${ }^{10}$ A postexilic sociocultural context for Ecclesiastes is most appealing as political and economic oppression was dominant in Ptolemaic and/or Hellenistic Palestine than it was in Solomonic era.

\section{The concept of hebel in Ecclesiastes}

The word hobl is unquestionably the book's literary centre, its piloting theme, functioning as the weaving thread and as the key to unlock its theological hub. The theme of 'under the sun' only ranks second to it (Eccl 1:3, 9, 14; 2:11, 17, $18,19,20,22 ; 3: 16 ; 4: 1,3,7,15 ; 5: 13,18 ; 6: 1,12$, etc.); then next to this is that of 'a chasing after the wind' (Eccl 1:14, 17; 2:11, $17,26 ; 3: 22 ; 4: 4,6,16 ; 6: 9)$. Hebel plays a ligamentary role in Ecclesiastes. It serves as the pervasive hub that holds together both the spokes and the wheel of the book's theological centre. Hebel [vanity of vanities] is the author's theme song (Boadt 1984:483) and as the key word serves as the inclusio that frames Qoheleth's teaching and gives the hermeneutical

10.This proposition is quite rational and more accommodating Yot tension still remains as neither the identity of the narrator, the fictitious Qoheleth, nor that of
the collector/editor is known to the modern reader. Extant scholarly proposals to the collector/editor is known to the modern reader. Extant scholarly proposals to
this extent remain speculative. Few still think that to dismiss completely Solomonic presence in Ecclesiastes on the ground of the type of Hebrew used requires caution. They reason that it is not impossible for the collector or editor of this wisdom material to write in the language of his time for the benefit of the Yehud readers as he seeks to reinterpret Israel's ancient wisdom tradition. They argue, for instance, that a rewriting of the works of William Shakespeare, for example, would obviously not use the linguistic structure of his day for the benefit of modern readers as this would be archaic to them. Hence, dating the work to an exclusively Persian, Ptolemaic and/or Hellenistic period of the fourth and 3rd century BC, ascribing authorship to one of the Jewish sages of this period disguised as the ascribing authorship to one of the Jewish sages of this period disguised as the Qoheleth (Scott 1965:201) appears to only work well for the book's compilation, editorial effects and finalisation rather than the major composition. As Longman (1998) rightly submits: so little is known about the transmission of the biblical tex during its earliest stages that we cannot rule out linguistic updating. The so-called late forms may not in fact have been original to the book but may reflect the updating of vocabulary and grammar by later scribes so their contemporaries could understand the book better (p. 10). 
context of his sayings (Waltke 2007:955-956). Waltke submits that its dual function stands in reference for that which is temporally fleeting and intellectually futile. Dulin corroborates this by suggesting that this key concept acts like a frame to give the book its unique character (2001:266).

Hebel is the dominant word in Ecclesiastes. Kiel Seybold says hebel occurs 73 times in the Masoretic Text and its denominative verb habhal five times. Over half of the occurrences of the noun in the OT occur in Ecclesiastes (1978:313). Reed (2012:155) specifically thinks hebel is used 38 times in Ecclesiastes out of the 73 occurrences in the entire Hebrew Bible. ${ }^{11}$ In his analysis, Seybold points out that hebel generally appears in the absolute. Its occurrence as comparative 'indicates that the term expresses an evaluation of people or things'. Also, its particle and adverbial use shows that hebel accomplishes a negative qualification (1978:314).

The Qoheleth's use of this theme indicates its negative overtones. The undergirding idea that clusters the concept of something considered as hebel (vanity or vain) is descriptive of its valuelessness, emptiness, meaninglessness, worthlessness, unbeneficialness and futileness. Hebel describes the unproductive activity that yields neither premium nor dividend that is individually or corporately beneficial. It expresses an evaluation of the life of worthless acquisition and a reckless and ungirded living that ends in futility. According to Reed, while Qoheleth uses hebel in a conventional way to take on a transient meaning, he usually employs an idiosyncratic meaning to move beyond its restriction to only human existence to everything else (2012:157). Hebel then is used by Qoheleth in reference to something that adds no value to life; that which is considered null, vain and yields no positive results (Reeds 2012:158). Here, the import of something that vanishes or that disappears into oblivion such as breath, vapour, smoke, worthless and not beneficial, would fit in appropriately; hence, the Qoheleth's descriptive term 'a chasing after the wind'.

Glenn (1985:976) also suggests a metaphorical meaning for hebel in reference to 'what is unsubstantial or without real value'. William Mounce writes that its metaphorical function denotes vanity, futility and/or temporality, used in three categories to refer to the worthless worship of false gods; to signify the unsubstantial or vain human efforts and to the temporality or futile nature of a thing (2006:763-764). In effect, the Qoheleth's scepticism about God and knowledge, according to Crenshaw, forces on him to question the question of questions - whether life does have meaning (1998:116). In essence, the use of hebel by Qoheleth questions the essence of existence and the insatiability of human quests.

But some have considered such negative conclusive declarations about life by the Qoheleth, presumably, as the 'expressions of his inability to find any reasonable explanation

11.Verse 2 in the prologue alone has three occurrences of this weaving thread or pervasive hub. It subsequently continues in $1: 14 ; 2: 1,11,15,17,19,21,23,26$; $3: 19 ; 4: 4,7,8,16 ; 5: 9 ; 6: 2,9,11 ; 7: 6 ; 8: 10,14 ; 11: 8,10 ; 12: 8$. for the events and circumstances he has set out to understand' (Shields 1999:121). Human life is declared vanity in its totality, so the Qoheleth claims: 'Vanity of vanities', says the Preacher; 'Vanity of vanities, all is vanity' (Eccl 1:212 NIV). The entirety of human life, from the empirical and experiential knowledge of the Qoheleth, is full of frustration and uncertainty because 'Nothing lasts, so nothing is worth striving for. Nothing satisfies, and in the end death comes to rich and poor, wise and foolish, righteous and wicked' (Routledge 2008:223). This irreconcilable dilemma makes the sense of resignation an overwhelming and compelling impression in the Qoheleth. He is compelled 'to submit in deep resignation to this tragic existence' of humanity's brief life (Von Rad 2005:458). Qoheleth's curious and passionate search in response to the question of the meaning of life, that is, to find a value that could make life worth living only heightens his pain as he is confronted with the perplexing and irreconcilable reality that even wisdom, riches, toil, success and posthumous fame alike were a 'vanity' (Von Rad 2005:455).

Such an exhalative tone 'appropriate to sadness' (Asa 2009:55) suggests the absolute transitory, absurd nature of things and in particular the seeming ephemeral and 'unpredictable quirks of existence' (Andrews 2001:299). Considered as a sign of dissatisfaction, such knots of discontent with reality pervades the book (Tamez 2001:253).

\section{The political and economic contexts for the use of hebel in Ecclesiastes}

The literary composition of Ecclesiastes like all other biblical literature grew out of specific political, economic, social, cultural and religious contexts. Political and economic oppression by people in privilege was a reality in NeoAssyrian, Neo-Babylonian and Persian societies, even right into the Graeco-Roman period. Kings of ancient societies were hungry for political and economic power and achievements. On this basis, they prided themselves in subjecting smaller nations under vassalage to their suzerain status to add to their pride of more political and economic gains. So also is the case with most powerful people who oppress and subjugate the vulnerable, poor, weak, voiceless and less privileged in society.

The pervasive presence of הֶר (hebel) in Ecclesiastes obviously indicates that the Qoheleth also used it in view of the oppressive political and economic behaviour or lifestyle prevalent in Ptolemaic and/or Hellenistic Palestine and elsewhere. The context of his statement about the hebel of everything in life arose from wisdom gained through observing the life of wealthy and self-confident people of the society vis-à-vis the plight of the poor and powerless. The Qoheleth approaches the issues of life 'through the

12. Robert McCabe says the Hebrew Qoheleth uses hebel as his catchword. However . McCabe himself prefers to use of breaths, says Qohelet, breath' of breaths, all is breath' (1996:88). Jason DeRouchie rather prefers 'enigma'; hence, he translates this verse as, 'Ultimate enigma, says the Preacher, ultimate enigma! All is an enigma' (2011:14). Peter Enns, however, translates hebel as 'absurdity' (2008:129). 
socioeconomic idioms current in his generation to address the preoccupations and obsessions of his audience' (Seow 2001:944). Obviously:

Qoheleth as a sage is well aware of himself as well as the social and historical circumstances in which he lived. His negative worldview is inextricably linked to the events of his day. (Middlemas 2007:219-220)

Majority of modern scholars favour a later context in the Ptolemaic and/or Hellenistic era but pre-Maccabean time for Ecclesiastes than a context earlier. Brown (2000) situates Ecclesiastes within a cultural context of malaise of turbulent economic change beginning from the Persian period. According to Collins, Palestine was under the rule of the Ptolemies throughout the 3rd century BCE. Consequently, it would be a mistake to think that Judea was immune to the cultural changes throughout this period (1997:24).

A liberated Judah from the Babylonian exile had to contend with surviving under foreign control from Persian, Hellenistic and Roman control. Although certain socio-economic developments dramatically changed the social landscape of Palestine, such rapid growth did not benefit all people equally (Brown 2000:9). In particular, the novelty Hellenistic era, described as 'a tightly organised moneymaking machine', was motivated by trade, boosted by the introduction and general use of coined money and improved technology (Collins 1997:25). Commerce in the Ptolemaic Palestine and/ or Hellenistic era, heavily taxed though, was controlled by royal officials and enjoyed by the wealthy families of local Jewish aristocrats.

The text of Ecclesiastes is therefore a clear criticism of the Hellenistic rulers and their representatives in Judea, namely Tobia Joseph, an egoist who grounded his contentment on wealth. According to Ecclesiastes 3:16 and 4:1-3, leaders did not care about the misery of the people who were used and oppressed to assist them in their pursuit of richness and happiness. The prevalence of slave trade, especially female slaves, between Egypt and Ptolemaic Palestine particularly became aberrant and abhorrent to the effect that 'the success of some was built on the misery of others' (Collins 1997:26). Unarguably, Ecclesiastes characterises a cultural context that is profoundly that of 'disillusionment with the past, uncertainty about the future, and a groping for new answers' (Brown 2000:8) in the postexilic Yehud community.

To this end, Qoheleth was addressing political and economic issues from an eyewitness perspective. The tone with which he addresses life's issues in Ecclesiastes, no doubt, reveals the author both as a keen observer and as an active participant in the drama of life. This probably made him to root his philosophical grid on the concept of hebel, grounded upon the warrant which proposes that human life consists of:

what is visible or recognizable, but unsubstantial, momentary, and profitless ... 'Everything in life is hollow and utterly futile' ... Man's self-conscious existence, his experience of life's struggle and all he tries to accomplish, turns out to be the merest vapour. (Scott 1982:202)
Consequently, Qoheleth uses hebel as an evaluative grid to critique and caution, particularly, the wealthy and powerful, arguing that the political and economic privilege that is not put to the benefit of human development and society's good is 'a chasing after the wind'.

As seen above, the Qoheleth reports his empirical observations about life in the Ptolemaic and/or Hellenistic Palestinian society reflectively. The presence of the pronominal phrase, 'I have seen', attests to this (Eccl 1:14; 3:10; 5:13; 6:1; 7:15; 9:11; $10: 5,7)$. He reflects on the oppressive sociology of his society, human pride of material possession and the irrational and undemocratic exercise of political power and the indiscriminate and flagrant use of economic privilege in the Palestine of his day and elsewhere. From such deep reflection, he arrived at the conclusion that this is a hebel. Furthermore, if the Qoheleth was a business or political executive, his diplomatic interaction in political and socioeconomic affairs with other international nations like Mesopotamia, Egypt and Greece (Murphy 1992:xxii, xlii) via transnational trade and politics might as well have aided his reflection and the inclusion of hebel as the leading theme of his literary product.

While a precise authorial identity remains uncertain, one fact clearly stands out - the descriptive use of hebel is the Qoheleth's interpretation of the empirical economic and political reality of his day to achieve a specific cautionary and advisory purpose to help people determine the real essence and value of human existence. All human efforts, after all, are a hebel. Nothing is worth the effort in the human quests to derive true satisfaction in this brief and transitory life, indicating that life's essence lies not in the indiscriminate use of political power or in material possession but rather in respect for Imago Dei, humanitarian services, and in the life of godliness.

\section{The social and political agenda for the Qoheleth's use of hebel}

The language of politics and royalty appears in various ways in Ecclesiastes (Eccl 1:12; 2:12). Qoheleth advised that the king's commands are to be obeyed by the subjects and the king himself is to be respected (Eccl 8:2-5; 10:20). Qoheleth reports that it is the mean operators of political power in society that oppress the poor, powerless and voiceless (Eccl $4: 1 ; 9: 14)$.

A political and economic reading of Ecclesiastes reveals a political agenda proposed by the Qoheleth. Such reading arises from an observed oppressive sociology of human experience usually perpetrated by those in privilege. A general feeling one gets from reading Garrett (1987) is his interpretation of the presence of political oppression and injustice in Ecclesiastes. This may not necessarily be the case as the rich and even some powerful persons who are not involved in politics equally oppress those lower than them in society. Yet, he was quite correct when he wrote, 'much of Ecclesiastes addresses the political arena' (1987:159). In his materialist reading, an effort that attempts to understand Qoheleth through the analysis and appraisal of his text with 
particular interest 'in the material necessities and comfort of the society' and/or 'with an interest in the socio-political aspect of the society', Ugwueye (2014:528) situates his discourse on theodicy. The political economic use of (hebel) in Qoheleth has a bearing on social justice as an aspect of society's communal life and corporate existence.

The exercise of political power that does not seek to achieve social justice, fairness and equity always works for the benefit of the perpetrators but to the detriment of the subjects. To this effect, those that exhibit an arrogant and brute-like attitude to exert a domineering, oppressive, brutal, manipulative and enslaving power on the powerless and voiceless of society (Eccl 4:1), simply because they have political power to their advantage, should heed the counsel of the experiential Qoheleth - they need to act and live morally upright (Eccl 9:10). This is significant; for after a person's demise, there remains no opportunity to either seek redress or to correct the wrongs and evils of the past (Eccl 5:16; 8:8; 9:3, 5). A person passes through this transitory and brief life and walks the path of it only once (Eccl 7:2).

In Qoheleth's opinion, those who perpetrate oppressive political systems are to learn lessons from the irony and enigmas of life - nothing and no present condition in life is permanent (Eccl 10:6-8). Here, Qoheleth draws attention to a 'competitive economic environment full of risk; a somewhat arbitrary one, [in a] rapidly changing world, where the newrich of today could easily be the new-poor of tomorrow' (Prior 2002:10). Those who have political power to their advantage should therefore consciously and considerately apply rational logical reasoning to its administration. For the Qoheleth, the unpredictability and temporality of human existence is a great enigma, serving as a great lesson to be learned by all humans. Life's indelible enigmas leave no chance for a detour. According to Seow (2001):

The inevitability of one's fate $(3: 15 ; 6: 10)$, the unavoidability of death $(3: 19)$, the repetitions of life $(3: 1-8)$ all walk together to create a vision of the remoteness, the inscrutability and ultimately the indifference of the world to the individual. (p. 944)

Readers are to resonate with the author and derive from these 'a hard-won wisdom: This is how the world is'.

A further irony of the abuse of political power, according to Qoheleth, is that 'Politics gives no lasting glory' (Garrett 1987:165). Worst of all:

Death not only permanently halts the quest for glory and power, but it renders the whole process meaningless; it is not only the person that dies, but all the glory he worked for as well. Whatever fame a person may have gained in life scarcely survives him. (p. $172)$

In Qoheleth's judgement, then, the execution of political power that fails to respect human dignity is not only an aberration but an oppressive evil (Eccl 4:1-2; 8:9). To him, the attitude of political oppression of society is rather to be replaced with a reverential attitude so as to achieve a tranquil life and finally a tranquil exit from existence (Eccl 8:11-13).
Qoheleth arrives at this conclusion from the agony of personal experience of the inappropriately gruesome use of political power by political administrators to their benefits. ${ }^{13}$

\section{The social and economic agenda for the Qoheleth's use of hebel}

Besides the political purpose discussed above, Qoheleth's use of (hebel) also has a social and economic agenda in view. Readers encounter the frequent occurrence of economic language in Ecclesiastes. Economic words such as 'wealth', 'possession', 'money' and 'riches' are extant in Ecclesiastes (Eccl 2:1-8, 18-21; 6:1-2; 5:8-10, 12-15). The Qoheleth used a politico-economic proposition to address the insatiable economic quest of the powerful. The 'I' sections indicate that the speaker was either a direct participant in economic events or took on the persona. He had embarked on agricultural projects (Eccl 2:4-6), the acquisition of material and human wealth that his political and economic might could afford (Eccl 2:7-8), and the acquisition of luxury amusers from the domain of musicology characteristic of royalty and the rich as an expression of his political and economic greatness (Eccl 2:8b-9). Even then, a self-evaluation brings Qoheleth's quest to the conclusion that all is hebel (Eccl 2:11). Ecclesiastes 2:111 reports Qoheleth's personal experience of his effort of combining economic and political acquisition, deployed ultimately with the purpose of deriving pleasure in life. Yet, Qoheleth dismisses it as hebel as his quest for optimum fulfilment in life climaxes in insatiability and frustration. Probably, in the persona of a backslidden Solomon, Qoheleth's life 'was meaningless because he had not himself relied on God as he should have' (Barker et al. 1995:984) in his quest for pleasure.

To further reiterate the point, readers would readily observe that Qoheleth's ground for the political and economic assessment of life that leads to his thesis of hebel is personal experience (Eccl 1:12-14). From his experiential taste of political and economic powers, pride and glamour (Eccl 2:49a), Qoheleth dismisses all as hebel for their satiable deficiency (2:11). Much economic acquisition without maximising its benefits is nothing but a hebel. The exit of the owner paves way to a foreign beneficiary that may likely not apply wisdom, prudence and rationality in its administration (Eccl 2:18-19,21). This, he says, is a grievous evil (Eccl 5:13-14; 6:2).

The economically powerful of society have the tendency to be oppressive of the poor because of greed. Ironically, the insatiable spirit of humans towards riches and wealth instead of contentment is a great expression of hebel (Eccl 5:8-12). The

13.Like the context of the lament of Psalm 73 indicates, Jews from wealthy families and those in royal and political privilege oppressed fellow Jews in Ptolemaic and/o Hellenistic Palestine. King Solomon was charged for such similar crimes in his day. For instance, from a social and ethical perspective, Solomon who was exceptionally wise, extremely rich and excessively powerful militarily used his political power at some point to oppress his subjects economically and laboriously (1 Kgs 12:3-4). He some point to oppress his subjects economically and laboriously (1 Kgs 12:3-4). He conscripted them into forced labour, just a little lighter than the experience of their patriarchs in Egypt. Taxation was also added so the king could build his roya palace, the temple and a citadel for his Egyptian bride (1 Kgs 3:1; 9:12-23). Despite the reality that Solomon's political alliance brought him materials for the building project (1 Kgs 5:1-12), he went ahead to conscript his subjects into forced labou or the work (1 Kgs 5:13-18) in addition to the foreigners he had enslaved. An objective reflection would have led him to the discovery that this, after all, is a hebel, 'a chasing after the wind'. 
warrant for this thesis is situated in the reality that the more riches and wealth one has acquired, the more one desires its addition. Worst of all, the more material and financial possessions one has, the more outlets are created to expend them (Eccl 5:10-11). This is really a hebel. According to the empirical discovery of the Qoheleth, the acquisition of wealth that is deficient in its humanitarian distribution is not only an encumbrance to human sociology but also an unfortunate hebel. The exit of the owner from existence does not allow for even an iota of a souvenir to the final destination to which he or she goes as all wealth must compulsorily be severed from its own at death (Eccl 2:18-19; 5:15-16).

Consequently, the antidote to such toilsome and grievous acquisition of wealth that is not enjoyed by the acquisitor or society, but unfortunately by a foreigner, is rather its optimum enjoyment in the purview of the divine giver with a reverential attitude (Eccl 2:24-26; 3:12-14, 22; 5:18-19; 8:15). Life's uncertainties and the constant flux of events suggest that the conditions of fortunes and misfortunes in human existence are not under human control. Nothing is permanent. What is considered a misfortune condition of a person today can turn into a great fortune tomorrow, and vice versa (Eccl 4:13-15). Just as one's time of exit from the earth is unpredictable, so is the experience of fortunes and misfortunes in human affairs. Therefore, no person is to be permanently exalted for one's societal status on the ground of material possessions, nor should any be despised on the basis of one's momentary disadvantaged condition. This then appeals to common sense how people are to live and relate in the human society.

To this end, Qoheleth's benediction regarding the indiscriminate, unreasonable and undemocratic use of economic power, situated in the concept of 'remembrance', is captured by the concluding chapter of Ecclesiastes. People who are materially and financially rich are to remember the imminent days of old age (12:1-5); they are to remember to do good and uphold the principles of justice, equity, fairness and the even distribution of wealth before their exit (12:6-7); they are to also remember that all human deeds, whether good or bad, will come under divine evaluation, justice and repudiation (12:14); and they are, lastly, to remember to offer a holistic reverence to God while they are still alive (12:13).

\section{The ground for the Qoheleth's use of hebel to evaluate the political and economic environments}

The Hebrew Qoheleth is a deeply religious person despite the reality that life confronted him with irreconcilable tensions. Middlemas draws attention to this when he states that it is an error to label him an atheist because of his belief in the existence of God. He submits, ' . . however unknowable and unreachable. Everything on earth takes place under the purview of the deity' (2007:219). The permeating presence of [ֶ, אֶדים [God] consistently used by the Qoheleth as a reference point for his ideological propositions about life affirms this reality. 'God' occurs no less than seven times without the article (Eccl 1:13; 3:10, 13; 5:18; 7:18; 8:2, 13) and for no less than 30 times with the definite article. For example, he states, God has placed a burden on the human race (Eccl 1:13; 3:10); a gift from God is deriving pleasure from creation and enjoying the labour of one's hand (2:24; 3:13); earthly existence, wealth and wisdom, et cetera are gifts from God (Eccl 5:18-19; 6:2; 9:9; 8:15); and so on. Qoheleth claims that all God has done to the cosmic order and given to human society is for the purpose of reverence for him and service to him (Eccl 3:13; 8:12; 12:13). To this extent, Scott is likely not correct to assume the Qoheleth as showing 'little interest in formal religion and most of its customs and traditional beliefs' (1982:200). One would rather likely reason with Glenn who thinks that although the dominant mood of the book of Ecclesiastes is pessimism, the author is not a pessimist, cynic or a sceptic. Glenn argues rather that 'he was a believer who sought to destroy people's confidence in their own efforts, their own abilities, their own righteousness and to direct them to faith in God as the only possible basis for meaning, value and significance to life "under the sun"' (1985:977).

Significantly, the motivating factor or ground for the Qoheleth's use of (hebel) is rooted in his experience of life and reality cast against religious consciousness. This generates his suggesting the appropriate methodology of life for the politically powerful and the economically oblivious of the society of his day. Roper and Groenewald quote Whybray as conceding Qoheleth as an independent thinker who provides a critical examination, not just of a distinct 'wisdom tradition', but of his own native religious tradition, enshrined in the Jewish scriptures (2013:3). According to Qoheleth, both political power and economic possession are to be exercised and enjoyed with prudence, sagacity, ethical rightness and religious consciousness (Eccl 2:26; 4:1; 5:10; 7:19). Of course, the religious orientation and consciousness in Qoheleth's thoughts would call for this consideration.

Waltke (2007:259-260) also draws attention to the religious thought of the Qoheleth when he said he counterbalances his empirical epistemology with reference to God and the fear of him. 'Qoheleth', he points out, 'expresses faith in God's wisdom to order life so as to make it beautiful in spite of its absurdities' (Eccl 3:1-11; 7:14; 8:17). Rational irreconcilable realities encountered in the Qoheleth are insufficient to dismiss the activities of a deity in human experience. In the face of irreconcilable contradictions as pointed out by Qoheleth, Reed is right to reason that 'he has given up on God's deliverance of individuals or the nation. Qoheleth has psychologically moved beyond protest to resignation and acceptance, and he wants his audience to do the same' (2012:162). This is where faith takes over human rationality; certain things in human experience and in life are better interpreted in light of faith than rationality to make sense. Amidst the irreconcilable paradox of life encountered in Job and Ecclesiastes, Branick points out, 'Qoheleth does not give an answer to the anguish of life, hemerely refers thematter toGodinhisincomprehensibility' (2006:82). Similarly, Craig G. Bartholomew points out that the exhortation to remember the creator in the epilogue of Ecclesiastes (12:1-8) is 'the equivalent of starting with the fear 
of the Lord. It means developing a perspective integrally shaped by a view of this world as being the Lord's' (2005:184).

According to Qoheleth's religious conceptual understanding, it is only when one who is in political authority or one with much wealth and riches gives space to religion that the creator will be pleased in this transitory existence. This is corroborated with the assertion of Proverbs, 'The fear of the LORD is the beginning of knowledge, but fools despise wisdom ...' (Prov 1:7 NIV; see also 2:4-6; 3:7; 8:13; 9:10). It is religious consciousness and grounding, far beyond human morality, in a person that gives right direction for political governance and provides the basis for the appropriate administration of one's wealth. Even in the act of governance, it is the appropriate combination of right religious and moral principles that achieves the administration of equity, fairness, justice and cohesive existence. That Qoheleth challenges the politically powerful and economically wealthy to place a premium on religion, consequentially, presupposes the reality of God. Life without the presence and control of the divine is, indeed, a hebel. Upon Qoheleth's discovery about the essence of life, he advocates a reversal of the life of self-centred political and economic irresponsibleness to the one centred on God (Eccl 12:13; 7:13-14).

\section{Conclusion}

The Qoheleth's use of (hebel) has direct consequence on the political and economic life of those who live in privilege in society. The tone of Qoheleth in Ecclesiastes suggests he knew close to almost everything about the experience of political wisdom and power and material possessions and pleasure as someone who was raised in privilege, or at least, one who was a careful observer of life. From his empirical data of the behaviour of royal officials and wealthy Jewish aristocrats of the Ptolemaic and/or Hellenistic context, the Qoheleth observed that their whole life was characterised by an ivory tower experience as they had at their disposal the benefit of power and wealth. Everything about and around them was framed and coloured with royal orchestration of an ivory tower sociology and environmental ideology. They appeared carefree and insensitive to human needs and pains. Readers should not therefore wonder why Qoheleth surprisingly speaks like a direct participant in the drama of political and economic life. He is an empiricist and a keenly meticulous observer who gives an on-the-spot account of unfairness in human society.

Undeniably, 'Qoheleth has an aristocratic flare' (Reed 2012:139) as one who has vast experience in an ivory tower and aristocratic ideology. But as a careful philosopher and an empiricist, and as an expressive pragmatic realist, who shares honestly his personal experiences and those observable in the affairs of the society of his day, the Qoheleth was standing in the tradition of those in the corridor of political and economic power to make effectual his use of hebel. His use of such vocabulary 'attacks the prosperity theology prevalent in his day which correlated character and the attainment of wealth' (Middlemas 2007:220). The purpose was to evaluate, critique, caution and deter by offering wise practical counsel to people in governance and those with the privilege of riches to tread life with utmost caution in view of the transitory and unpredictable nature of things and of existence itself. Such a guiding principle would redirect the affairs of people who are more concerned with the quest to amass more wealth and more recognition at the corridor of power for perpetual political and economic control (see Eccl 4:8; 5:10; 6:9). The possession of political as well as the acquisition of economic power devoid of religious consciousness and respect for human Imago Dei makes one's existence a hebel.

Consequently, from an empirical and experiential stand point, the Qoheleth draws the attention of the political and economic class in society, those who might have been blinded by these things and who jettisoned the pursuit of good moral character and acts of godliness, to the reality of the real life and to what its true essence should be. Qoheleth calls attention to 'the total insecurity of life ... to warn against illusions' (Von Rad 2005:456) and to the deceit of power and wealth. By this, he aims to refocus politicians, monarchs, nobles and the wealthy to the application of universal moral laws for a good human society.

\section{Acknowledgements Competing interests}

The author declares that he has no financial or personal relationships which may have inappropriately influenced him in writing this article.

\section{References}

Asa, R., 2009, 'The faith of a skeptic: The enigma of Ecclesiastes', Journal for the Liberal Arts and Sciences 13(3), 55-66.

Andrews, S.R., 2001, 'Ecclesiastes 7:1-19', Interpretation July, pp. 299-301. https:// doi.org/10.1177/002096430005500309

Barker, K. (gen. ed.), Burdick, D., Stek, J., Wessel, W. \& Youngblood, R. (assoc. eds.), 1995, The NIV study Bible, 10th anniversary ed., Baker Academic, Grand Rapids, MI.

Bartholomew, C., 1999, 'Qoheleth in the Canon? Current Trends in the Interpretation of Ecclesiastes', Themelios 24(3), 4-20.

Bartholomew, C.G., 2005, 'Ecclesiastes, book of', in K.J. Vanhoozer (gen. ed.), C.G. Bartholomew, D.J. Treier \& N.T. Wright (assoc. eds.), Dictionary for theological interpretation of the Bible, pp. 182-185, Baker Academic, Grand Rapids, MI.

Boadt, L., 1984, Reading the Old Testament: An introduction, Paulist Press, New York.

Branick, P.V., 2006, 'Wisdom, pessimism, and "MIRTH" reflections on the contribution of Biblical wisdom literature to business ethics', Journal of Religious Ethics 34(1), 69-87. https://doi.org/10.1111/j.1467-9795.2006.00256.x

Brown, W.P., 2000, Ecclesiastes: Interpretation, Westminster John Knox, Louisville, KY.

Chisholm, R.B., Jr., 1998, From exegesis to exposition, A practical guide to using biblical Hebrew, Baker Books, Grand Rapids, MI.

Collins, J.J., 1997, Jewish Wisdom in the Hellenistic Age, Westminster John Knox, Louisville, $\mathrm{KY}$.

Crenshaw, J.L., 1998, Old Testament wisdom: An introduction, revised and enlargedWestminster John Knox Press, Louisville, KY.

Curkpatrick, S., 2001, 'A disciple for our time: A conversation', Interpretation July, pp. 285-291. https://doi.org/10.1177/002096430005500306

DeRouchie, J.S., 2011, 'Shepherding wind and one wise shepherd: Grasping for breath in Ecclesiastes', Southern Baptist Journal of Theology 15(3), 4-25.

Dulin, R.Z., 2001, “'How sweet is the light”: Qoheleth's age-centered teachings', Interpretation July, pp. 260-270. https://doi.org/10.1177/002096430005500304

Enns, P., 2008, 'Ecclesiastes 1: Book of', in T. Longman, III \& P. Enns (eds.), Dictionary of the Old Testament: Wisdom, poetry \& writings, pp. 121-132, Inter-Varsity Press, Nottingham, England.

Garrett, D.A., 1987, 'Qoheleth on the use and abuse of political power', Trinity Journal 8 NS, 159-177. 
Glenn, D.R., 1985, 'Ecclesiastes', in J.F. Walvoord \& R.B. Zuck (eds.), The Bible knowledge commentary, reprint, pp. 975-1007, SP Publications, Wheaton, IL.

Habtu, T., 2006, 'Ecclesiastes', in T. Adeyemo (ed.), Africa Bible commentary, pp. 787-796, Word Alive Publishers, Nairobi, Kenya.

Hamilton, V.P., 2004, Handbook on the historical books, reprintBaker Academic, Grand Rapids, MI.

Harrison, R.K., 1969, Introduction to the Old Testament, Eerdmans, Grand Rapids, MI.

Hendry, G.S., 1981, 'Ecclesiastes', in D. Guthrie, A. Motyer, A.M. Stibbs \& D.J. Wiseman (eds.), The new Bible commentary, 3rd edn., reprint, pp. 570-578, Inter-Varsity Press, London.

Ingram, D., 2013, 'The riddle of Qoheleth and Qoheleth the riddler', Journal for the Study of the Old Testament 37(4), 485-509. https://doi.org/10.1177/03090 89213483978

Jackson, D.R., 2008, 'Solomon', in T. Longman, III \& P. Enns (eds.), Dictionary of the Old Testament: Wisdom, poetry and writings, pp. 733-737, Inter-Varsity Press, Nottingham, England.

Kidner, D., 1992, 'Poetry and wisdom literature: Introduction', in P. Alexander \& D. Alexander (eds.), The lion handbook to the Bible, paperback edn., pp. 316-318, Lion Publishing, Oxford, England.

Levicheva, L.I., 2014, 'Contentment in the book of Ecclesiastes: Interplay of the themes of death, the role of God, and contentment in Qoheleth's teaching', A thesis submitted for the degree of doctor of philosophy to Middlesex University, London.

Longman, T., III, 1998, The book of Ecclesiastes, The new international commentary on the Old Testament, Eerdmans, Grand Rapids, MI.

Longman, T., III, 2008, 'Ecclesiastes 3: History of interpretation', in T. Longman, III \& P. Enns (eds.), Dictionary of the Old Testament: Wisdom, poetry \& writings, pp. 140-149, Inter-Varsity Press, Nottingham, England.

Longman, T., III \& Dillard, R.B., 2007, An introduction to the Old Testament, 2nd edn., Inter-Varsity Press, Nottingham, England.

McCabe, R.V., 1996, 'The message of Ecclesiastes', Detroit Baptist Seminary Journal 1 , 85-112.

Meek, R.L., 2016, 'Twentieth - And twenty-first - Century readings of hebel (הבֶל) in Ecclesiastes', Currents in Biblical Research 14(3), 279-297. https://doi. org/10.1177/1476993X15586039

Middlemas, J., 2007, 'Ecclesiastes gone "sideways"', The Expository Times 118(5), 216-221. https://doi.org/10.1177/0014524606075051

Miller, D.B., 2000, 'What the preacher forgot: The rhetoric of Ecclesiastes', The Catholic Biblical Quarterly 62, 215-235.

Mounce, W.D. (ed.), 2006, Mounce's complete expository dictionary of Old \& New Testament words, Zondervan, Grand Rapids, MI.
Murphy, R.E., 1992, Word biblical commentary volume 23A: Ecclesiastes, Word, Dallas, TX.

Prior, J., 2002, 'When all the singing has stopped Ecclesiastes, a modest mission in unpredictable times', International review of missions $\mathrm{XCI}(360)$, 7-23. https://doi. org/10.1111/j.1758-6631.2002.tb00324.x

Provan, I.W., 2001, The NIV application commentary: Ecclesiastes, Song of Songs, Zondervan, Grand Rapids, MI.

Reed, M.R., 2012, The politics of pessimism in Ecclesiastes, Society of Biblical Literature, Atlanta, GA.

Roper, L.A. \& Groenewald, A., 2013, 'Job and Ecclesiastes as (postmodern?) wisdom in revolt', HTS Teologiese Studies/Theological Studies 69(1), Art. \#2002, 1-8. https:// doi.org/10.4102/hts.v69i1.2002

Routledge, R., 2008, Old Testament theology: A thematic approach, Apollos, Nottingham, England.

Rudman, D., 1999, 'A note on the dating of Ecclesiastes', The Catholic Biblical Quarterly 61, 47-52.

Scott, R.B.Y., 1965, The anchor Bible volume 18: Proverbs and Ecclesiastes, 2nd edn., Doubleday \& Company, Garden City, NY.

Scott, R.B.Y., transl. \& ed., 1982, The anchor Bible volume 18: Proverbs-Ecclesiastes, 2nd edn., reprint, Doubleday and Company, New York.

Seow, C., 2001, 'Ecclesiastes', in M.D. Coogan, M.Z. Brettler, C.A. Newsom \& P. Perkins (eds.), The new Oxford annotated Bible, 3rd edn., pp. 944-958, Oxford University Press, Oxford.

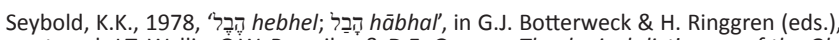
transl. J.T. Wallis, G.W. Bromiley \& D.E. Greene, Theological dictionary of the Old Testament, vol. III, pp. 313-320, Eerdmans, Grand Rapids, MI.

Shields, M.A., 1999, 'Ecclesiastes and the end of wisdom', Tyndale Bulletin 50(1), 117-139.

Tamez, E., 2001, 'Ecclesiastes: A reading from the periphery', Interpretation July, 250-259. https://doi.org/10.1177/002096430005500303

Ugwueye, L.E., 2014, 'God-justice versus evil in Qoheleth, a materialist interpretation', Mediterranean Journal of Social Sciences 5(8), 528-532.

Von Rad, G., 2005, Old Testament theology volumes I \& II, transl. D.M.G. Stalker, Peabody, MA.

Waltke, B.K., 2007, An Old Testament theology: An exegetical, canonical, and thematic approach, Zondervan, Grand Rapids, MI.

Wright, S.J., 1991, 'Ecclesiastes', in F.E. Gaebelein (gen. ed.), The expositor's Bible commentary, vol. 5, pp. 1137-1199, Zondervan, Grand Rapids, MI.

Zuck, R.B., 1991, 'A theology of the wisdom books and the Song of Songs', in R.B. Zuck \& E.H. Merrill (eds.), A biblical theology of the Old Testament, pp. 207-255, Moody Press, Chicago, IL. 